\title{
Strategic situational planning and management of pharmaceutical services and supply: The experience of a municipality in the State of São Paulo with regard to optimizing spending on medicinal lawsuits
}

\author{
Amanda Patrícia Favaron Portella1, Samara Jamile Mendes ${ }^{\circledR 2^{*}}$, Raquel Queiroz de Araújo ${ }^{3}$, \\ Brunno Carvalho Gastaldo ${ }^{4}$, Silvana Nair Leite ${ }^{\circledR 1}$, Silvia Storpirtis ${ }^{2}$
}

\begin{abstract}
${ }^{1}$ Pharmaceutical Sciences Department, Federal University of Santa Catarina, Florianópolis, SC, Brazil, ${ }^{2}$ Pharmaceutical Sciences Department, Faculty of Pharmaceutical Sciences, University of São Paulo, São Paulo, SP, Brazil, ${ }^{3}$ Pharmaceutical, Division of Pharmacy, São Paulo State Public Servant's Hospital, São Paulo, Brazil, ${ }^{4}$ Centre for Natural Sciences and Humanities, Federal University of ABC, Santo André, Brazil
\end{abstract}

\begin{abstract}
One of the actions taken was to offer training on pharmaceuticals via the distance education model (EAD) with the course titled Pharmaceutical Services and Supply Management Course (PSSMC). PSSMC, which was based on the idea of expanded management, is guided by Strategic Situational Planning (PES) concepts, and structured around an Operational Plan (OP) that serves as a practical didactic tool. The aim of this study is to report and analyze a case study based on the implementation of the Operational Plan in a municipality in the State of São Paulo, while focusing on the judicialization of access to medicines and health products. Since judicialization is an important topic, the problem chosen for resolution with the PES was attendance at the issuance of court orders by the municipality for items of medium and high complexity. The PES allows researchers to analyze reality through different points of view, of which participation is a key aspect. With the OP, it was possible to disseminate a proposal for expanded planning, to advance resolution of the problem, achieve positive results, and reduce expenses associated with the municipality's legal actions.
\end{abstract}

Keywords: Strategic Planning. Judicialization. Pharmaceutical services.

\section{Highlights}

$\checkmark \quad$ Of fourteen problems listed, the most important was attendance at the issuance of court orders by the municipality for high cost medicines

$\checkmark \quad$ Planning made it possible to advance activities that depended on the Judicial Actions Department

$\checkmark \quad$ The great advantage of strategic planning was that it initiated dialogue between subjects involved in the same planning activities, in which political feasibility played a central role

\section{INTRODUCTION}

For a long time, Pharmaceutical Police has been

\footnotetext{
*Correspondence: S. J. Mendes. Faculdade de Ciências Farmacêuticas, Universidade de São Paulo. Av. Prof. Lineu Prestes, 580 - Conj. das Químicas, Bloco 13 - Cidade Universitária, Butantã, CEP: 05508-900 - São Paulo, SP Brazil. E-mail: samarajm@gmail.com
}

seen from a minimalistic perspective, in which its actions were focused only on the acquisition and distribution of medicines; it did not consider how the services were organized or planned, and did not attempt to guide the offer of medicines to the population and in support of health actions (Brazil, 2006; Leite et al., 2016). Since the Brazilian National Pharmaceutical Policy on was recognized as part of the National Health Policy and involved a set of actions aimed at the promotion, preservation, and recovery of health with medicines as an essential input. It was necessary to rethink the organization and plan the Policy actions, to ensure access to medicine and rationalize its use in Brazil (Brazil, 2004). Pharmaceutical Assistance was organized through the drug financing components, called basic that provide medicines for the most common diseases via primary health care units, access to medicines for the prevention, treatment endemic diseases is the strategic component and 
medications whose care strategies have been defined in clinical protocols and therapeutic guidelines are provided in the specialized component (Leite et al., 2016; Chieffi, Barradas, Golbaum, 2017).

Pharmaceutical policy became an important aspect of the management of health system and there was a need to qualify the pharmaceutical services and supply in the context of Health Networks, and within the Unified Health System (SUS). The Ministry of Health, through the Department of Pharmaceutical Assistance and Strategic Inputs, has developed the National Qualification Program for Pharmaceutical Assistance (QUALIFAR-SUS) (Brazil, 2016). The Education Axis which offers training to health professionals using the distance education model (EAD)was created under this program and, in this research, we highlight the Pharmaceutical Services and Supply Management Course (PSSMC). Two editions of the course were performed to train 2500 pharmacists working in municipalities all over Brazil (Santos et al., 2016).

The global pursuit of universal health care coverage, however, has put a spotlight on the important role governance plays in achieving health and development goals, as well in improving the performance of health systems and programs (Siddiqia et al., 2009). Governance is defined in various ways. Broader definitions encompass politics, policies, public administration, and the interactions of these elements with civil society and the private sector, plus the effects that various institutions have on socioeconomic outcomes (WHO, 2014). Consequently, governance requires political and technical action (Mutale et al., 2013) and civil society engagement (Siddiqia et al., 2009).

Matus offered a theoretical reflection on public sector governance in Latin America (Spinelli, 2012). He argued that governance is not just a technical action, and neither is it just a political action (Matus, 1993). Junquillo (2001) and Barreto and Guimarães (2010), based on Matus, conceive of governance as a technical, political, and social action aimed at generating results that will meet the population's needs. Furthermore, Matus introduced a communicative vision of the theory of planning, which had until then been dominated by an economistic, technocratic, and divisive paradigm of politics-the so-called normative paradigm. The author reconceptualized planning, which was subsequently understood to be an eminently interactive process, thereby replacing the concept of planning as the knowledge and work of the ruler, operating within predetermined and stable contexts (Rivera, 2011).

Analyzing the concept of Strategic Situational Planning (PES), Matus (1993) reflects on normative planning and affirms that this kind of planning does not allow social actors to address their reality, being scarcely instrumental, strategic, reflexive, and communicative. PES is closely related to reality analysis, which changes rapidly. Strategic thinking in terms of health planning allows us to adapt to a changing context, which is essential, given the speed at which reality changes (Leite et al., 2016). In this theoretical context a better understanding of the role of pharmaceutical services and supply management in municipalities was needed. The PSSM Course is therefore based on the concept of expanded management (Barreto, Guimarães, 2010), is guided by Strategic Situational Planning (PES), and framed around an Operational Plan (OP) that serves as a practical and didactic tool.

Considering also that judicialization can be understood as a consequence of the current state of pharmaceutical management in Brazil, this study reports on and analyzes a case study of the implementation of an Operational Plan in a municipality in the State of São Paulo, while focusing on the judicialization of access to medicines and health products.

\section{METHODOLOGY}

This study reports on an actual experience with the development of a strategy aimed at quality improvement, and reviews the collection of witnesses, case reports, and cases that are related to the creation of records, while referring to WHO for similar models (Bireme/Opas/Oms, 2015).

\section{Study location}

This study, which deals with all the demands made for medicines, nursing items, diets, and food supplements was conducted in the Judicial Actions Department of the Municipal Department of Health in a municipality in the State of São Paulo. This Department comprises four public servants two pharmacists, a pharmacy technician, and an administrative assistant who work exclusively on serving court orders.

\section{Data collection and analysis}

Data were collected through the development of an Operational Plan (OP) that corresponds to one of the didactic activities undertaken by a pharmacist enrolled in the Pharmacy Assistance Management Course. The theoretical framework used for the OP was proposed by Barreto and collaborators (2016), and involved the use of instruments for the four "moments" explanatory, normative, strategic, and tactical-operational that comprise Matus' (1993) Strategic Situational Planning approach. 
The OP was developed between April 2014 and February 2015, and the results were analyzed on the basis of the researchers' experiences while living in the context of the Judicial Actions Department, previously cited. The life experiences documented here describe the planning process undertaken to resolve a problematic situation, and analyze the critical points in this process.

\section{Ethical aspects}

This work was based on an existing database analysis, and information describing the Pharmaceutical Services and Supply Management Course - EAD. This study is part of a project called "Pharmaceutical services developed under the Unified Health System and training in the EAD modality," with the approval of the UFSC Research Ethics Committee (CAAE: 46912815.0.0000.0121).

\section{RESULTS}

Under the Operational Plan that was developed as a didactic activity in the Pharmacy Assistance Management Course, it was possible to describe the authors' first-hand experiences with the planning process for the Municipal Department of Health in a municipality in the State of São Paulo. The results are organized around four PES moments.

\section{Explanatory moment}

During the first moment of the PES process, individual problems are identified and prioritized, their causes and consequences explained in depth, and the problems are described in words. These aspects are then depicted in the Ishikawa diagram (Lacerda et al., 2016). At the beginning of the explanatory moment, the Operational Plan's focus had already been defined as the Department of Judicial Actions of the Municipal Department of Health, since this unit faces increasing demands and difficulties in terms of the number of actors involved in the process. Conflicts regarding deadlines, procedures, bureaucratization, and responsibilities affect its compliance with judicial decisions.

This Department is also constrained by other problems, such as the decentralization of activities, the lack of infrastructure, municipal delays in updating the list of standardized medications due to the lack of an active Pharmacy and Therapeutics Commission, and the absence of an approved public budget, due to difficulties associated with predicting demand.
Ten people were invited to participate in a workgroup. They included a representative from each sector related to the flow of lawsuits: the City Attorney's Office, the Pharmaceutical Supply Center (CAF), the Judicial Actions Department, the Department of Health, the Administrative Department, the Procurement Office, the Secretary of Health Cabinet, and the Secretariat of Administration. This workgroup's initial task was to list and prioritize the department's problems. It should be noted that a fundamental principle of PES is involving the people affected by the problem to participate in its resolution, thereby legitimizing the process, and facilitating its implementation. Each participant was asked to identify one or more problems related to the Judicial Actions Department that they considered significant, after which the problems were discussed by the whole group.

Thus, during the workshop, members of the group were able to develop the entire explanatory moment, namely, they were able to prioritize the problem, determine its causes and consequences, confirm the descriptors and construction of the Ishikawa diagram, and determine the objective image (the ideal situation that would result from resolving the problem).

The Judicial Actions Department faced fourteen problems:

1. Lack of a proper and adequate infrastructure

2. Lack of employees in the various sectors to deal exclusively with lawsuits

3. High costs associated with lawsuits

4. Bureaucratization of the acquisition processes

5. Inappropriate workflow

6. Absence of a Pharmacy and a Therapeutics Committee in the municipality

7. Attendance at the issuance of municipal court orders referring to high cost medicines.

8. Difficulties returning inadequate products to suppliers due to the lack of ideal supply conditions

9. Increasing judicial demands for items provided by the SUS

10. Requiring that supplies be commercial brand-name items and non-acceptance of similar more affordably priced items

11. Suppliers failure to obtain Sanitary Permit and Operating Licenses

12. Slow responses to the inquiries made by the Department of Judicial Actions by the Municipal Attorneys

13. Difficulties obtaining approved budgets for the items to be acquired, and the Secretariat of Administration and Legal Affairs' unwillingness to accept alternatives or provide justifications for delaying the process 
14. Providing items for patients under home hospitalization by the medical insurance plan

The problems listed were organized according to the problem-prioritization matrix (Table I). The participants used the following criteria to prioritize the problems: magnitude (size), transcendence (interest), vulnerability (reversion), urgency (waiting) and feasibility (resources). Each problem was individually scored on each criterion employing a scale from zero (less important) to four (more important).

The problem prioritized as most significant (Table I - item 7 - 116 points) was "Attendance at the issuance of municipal court orders referring to high cost medicines, not related to primary health care" It was evident that participants assigned the highest scores to the problems directly related to their responsibilities, and all showed a great concern for the amount of money spent by the department. Following prioritization of the problems, it was suggested that the group have some further discussions on related matters, and the Ishikawa diagram was sketched. Sketching the diagram helped participants formulate the descriptors, whose function is to reveal why the prioritized situation is really a problem:

- Divergence, in the reality of the Judicial Actions Department, from what is dictated in Administrative Rule No. 5554, as of July 30, 2013, defines the Federated Institutions' responsibilities with regard to medicine and treatments
- Of the amount spent on lawsuits in the municipality in this study, $77 \%$ is intended for the acquisition of medium and high complexity medicines or procedures, not of primary health care responsibility (as described in SUS rules about hierarchy of care and levels of responsibilities).

- An increasing number of court orders against the municipality that refer to items of medium and high complexity, not for the primary health care.

- A large number of actions that are the shared responsibility of federated entities are served exclusively by the municipality

After defining the descriptors, each participant analyzed the causes and consequences for each descriptor independently. Responses to the key question, "Why does this occur?" served to identify causes, and responses to the question, "What does this generate?" clarified the consequences. The participants identified minor problems related to the descriptors that led to the main problem, and confirmed that different descriptors were related to the same cause. Nine causes and six consequences were identified for the four descriptors, making it possible to define the convergent cause and the convergent consequence. With the development of the OP, participants tried to determine the means for resolving the convergent cause, eliminating the convergent consequence, and achieving the objective image. The causes and consequences are detailed in Table II, and the Ishikawa Diagram is shown in Figure 1.

TABLE I - Matrix problem-prioritization concerning the Judicial Actions Department of the municipality under study (sum of the individual scores of the ten workshop participants)

\begin{tabular}{|c|c|c|c|c|c|c|}
\hline \multirow{2}{*}{ Problem } & Magnitude & Transcendence & Vulnerability & Urgency & Feasibility & \multirow{2}{*}{ Total } \\
\hline & Size & Interest & Reversion & Waiting & Resources & \\
\hline 1 & 15 & 14 & 14 & 14 & 12 & 69 \\
\hline 2 & 13 & 10 & 12 & 14 & 10 & 59 \\
\hline 3 & 19 & 21 & 10 & 16 & 12 & 78 \\
\hline 4 & 20 & 19 & 17 & 21 & 14 & 91 \\
\hline 5 & 10 & 10 & 19 & 7 & 20 & 66 \\
\hline 6 & 16 & 16 & 12 & 17 & 14 & 75 \\
\hline 7 & 25 & 20 & 25 & 22 & 24 & 116 \\
\hline 8 & 9 & 7 & 13 & 25 & 11 & 65 \\
\hline 9 & 23 & 20 & 16 & 17 & 14 & 90 \\
\hline 10 & 15 & 10 & 10 & 10 & 11 & 56 \\
\hline 11 & 13 & 7 & 10 & 13 & 9 & 52 \\
\hline 12 & 11 & 12 & 15 & 16 & 13 & 67 \\
\hline 13 & 15 & 13 & 10 & 11 & 9 & 58 \\
\hline 14 & 13 & 12 & 12 & 12 & 13 & 62 \\
\hline
\end{tabular}


TABLE II - Causes and consequences of the explanatory moment

\begin{tabular}{|c|c|c|}
\hline Descriptors & Causes & Consequences \\
\hline $\begin{array}{l}\text { Divergence in the reality of the Judicial } \\
\text { Actions Department from Administrative } \\
\text { Rule No. 5554, as of July 30, 2013, } \\
\text { which defines the responsibilities of the }\end{array}$ & $\begin{array}{l}\text { Judiciary's lack of technical knowledge } \\
\text { to assign responsibility for the actions to } \\
\text { the Federated Institutions according to } \\
\text { the complexity of the treatment. }\end{array}$ & $\begin{array}{l}\text { Difficulty in planning. } \\
\text { Expenses greater than the budget reserve }\end{array}$ \\
\hline $\begin{array}{l}\text { Federated Institutions in controlling the } \\
\text { complexity of medicines and treatments. }\end{array}$ & $\begin{array}{l}\text { Absence of a competent technical team } \\
\text { to instruct the judiciary. }\end{array}$ & Exceed the municipality's capabilities. \\
\hline \multirow{2}{*}{$\begin{array}{l}\text { Of the amount spent on lawsuits in } \\
\text { the municipality, } 77 \% \text { is intended for } \\
\text { the acquisition of medium and high } \\
\text { complexity items. }\end{array}$} & $\begin{array}{l}\text { The municipality does not meet the } \\
\text { demand, and is not contemplated in } \\
\text { REMUME. }\end{array}$ & \\
\hline & $\begin{array}{l}\text { The need to reallocate the financial } \\
\text { resources of primary care. }\end{array}$ & \\
\hline \multirow{5}{*}{$\begin{array}{l}\text { Increase in the number of court orders } \\
\text { against the municipality referring to } \\
\text { items of medium and high complexity. }\end{array}$} & $\begin{array}{l}\text { Unsatisfactory drug standardization } \\
\text { to meet the specific demands of the } \\
\text { population. }\end{array}$ & \\
\hline & $\begin{array}{l}\text { There is no communication flow } \\
\text { between the three spheres of }\end{array}$ & $\begin{array}{l}\text { One restricted portion of the population } \\
\text { benefits. }\end{array}$ \\
\hline & $\begin{array}{l}\text { government to define patients' special } \\
\text { needs. }\end{array}$ & $\begin{array}{l}\text { Non-compliance with the SUS principle } \\
\text { of equity. }\end{array}$ \\
\hline & $\begin{array}{l}\text { Emergence of new technologies and } \\
\text { treatment alternatives. }\end{array}$ & $\begin{array}{l}\text { Acquisition of the latest generation of } \\
\text { medicines, often without proof of their }\end{array}$ \\
\hline & $\begin{array}{l}\text { Lobbying by the pharmaceutical } \\
\text { industry of physicians. }\end{array}$ & $\begin{array}{c}\text { effectiveness and without registration in } \\
\text { ANVISA. }\end{array}$ \\
\hline \multirow{3}{*}{$\begin{array}{l}\text { High numbers of actions shared by } \\
\text { federated entities are served exclusively } \\
\text { by the municipality. }\end{array}$} & $\begin{array}{l}\text { Lack of technical knowledge by the } \\
\text { judiciary to assess the real needs of the } \\
\text { patients. }\end{array}$ & \\
\hline & $\begin{array}{l}\text { Absence of a competent technical team } \\
\text { to instruct the judiciary. }\end{array}$ & \\
\hline & $\begin{array}{c}\text { Guarantee of integral care by the Federal } \\
\text { Constitution through SUS. }\end{array}$ & \\
\hline
\end{tabular}

The other OP moments were formulated during workshop discussions. In an attempt to maintain a collective planning structure, participants received the OP by e-mail, so they could continue to offer suggestions.

\section{Normative moment}

The normative moment defined the concrete actions needed to achieve the objective image (Normative moment matrix - Table III). The general objective, the specific objectives, the operations, and the actions needed to solve the prioritized problem were defined (Lacerda et al.,
2016). Identifying the general objective of a "reduction of expenses with lawsuits" was simple, since the participants' greatest concern was the amount spent on lawsuits. The amount of lawsuits impacts also in other costs, such in human resources and infrastructure to support the acquisition, storage and dispensing of the medicines and health products or authorization for procedures.

Table III. Normative moment matrix.

\section{Strategic moment}

The strategic moment analyzed the difficulties and 


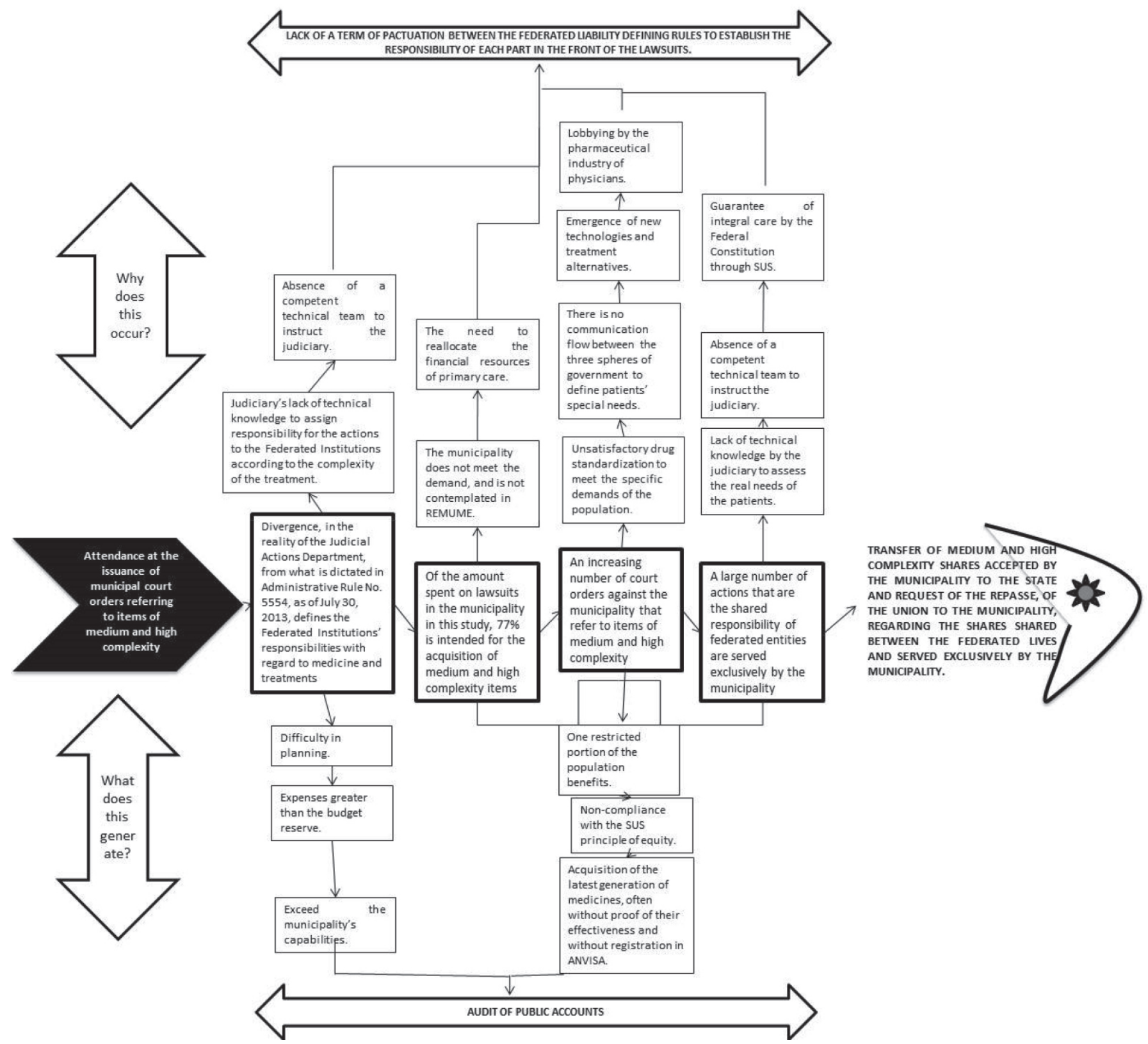

FIGURE 1 - Ishikawa Diagram based on the following priority problem: "Management process for municipal court orders of medium and high complexity".

facilities that could interfere with the fulfillment of the actions defined in the normative moment. It relates to the question of feasibility, and, therefore, to the obstacles that need to be overcome to bring reality closer to that described in the objective image. These aspects are related to the viability, feasibility, deficiencies, and strategic activities of each proposed action (Lacerda et al., 2016).

The actions were then analyzed, and led to a reckoning of which of these could only be undertaken by the Judicial Actions Department, which would have the power to decide, implement, and maintain them (governability), as well as which of these would depend on other sectors. The resources available were confirmed, as were the actions to be carried out. A strategic activity intended to sensitize professionals with the power to decide, implement, and maintain operations and viable actions was also proposed.

By analyzing viability, it became apparent that the Judicial Actions Department would have the power to decide on $83 \%$ of the actions proposed, while the state or municipality would have the power to execute and maintain $33 \%$ of the actions. From this it was concluded that reaching the general objective would require the involvement and the commitment of other actors. 
TABLE III - Normative moment matrix

\begin{tabular}{|c|c|c|}
\hline \multicolumn{3}{|c|}{ General Objective: Reduction of expenses associated with lawsuits } \\
\hline Specific Objectives & Operations & Actions \\
\hline $\begin{array}{l}\text { Reduce the number of shared high and } \\
\text { medium complexity court cases served by } \\
\text { the municipality. }\end{array}$ & $\begin{array}{c}\text { Establish criteria for technical defense } \\
\text { of the municipality with the Municipal } \\
\text { Health Department to provide support } \\
\text { to the judiciary for the exclusion of the } \\
\text { municipality from these actions. }\end{array}$ & $\begin{array}{l}\text { Bring together all technical staff } \\
\text { responsible for the technical advice for } \\
\text { defense of the municipality, combine the } \\
\text { procedures that will be done, and establish } \\
\text { a standard form for these cases. }\end{array}$ \\
\hline \multirow{5}{*}{$\begin{array}{l}\text { Reduce the expenses associated with } \\
\text { items of medium and high complexity. }\end{array}$} & \multirow[t]{2}{*}{$\begin{array}{l}\text { Transfer responsibility for managing } \\
\text { these lawsuits to the state. }\end{array}$} & $\begin{array}{l}\text { Direct negotiations with the Secretary } \\
\text { of the State of Sao Paulo regarding the } \\
\text { management of shared actions, so that the } \\
\text { municipality satisfies all the injunctions } \\
\text { for the primary care items and the state } \\
\text { handles the items of greater complexity. }\end{array}$ \\
\hline & & $\begin{array}{l}\text { Write a term of agreement to comply with } \\
\text { court orders, defining the responsibility of } \\
\text { each institution. }\end{array}$ \\
\hline & \multirow{3}{*}{$\begin{array}{l}\text { Collection of the Union Concerning } \\
\text { actions shared serviced by the } \\
\text { municipality. }\end{array}$} & $\begin{array}{l}\text { Carry out a survey of the shared actions } \\
\text { between the municipality and the Union. }\end{array}$ \\
\hline & & $\begin{array}{l}\text { Provide confirmations of the delivery of } \\
\text { the items relating to the shared actions. }\end{array}$ \\
\hline & & $\begin{array}{l}\text { Prepare a report defining the financial } \\
\text { portion of the responsibility of the Union } \\
\text { for reimbursement of the municipality. }\end{array}$ \\
\hline
\end{tabular}

Analyzing feasibility, it was observed that human resources, political interests, technical support, financial resources, material resources and the consent of the municipal secretaries involved would be needed to undertake all actions.

Four strategic activities were proposed to solve the prioritized list of problems:

- Raise the judiciary's awareness of the importance of distributing lawsuits according to their complexity, thereby reducing the burden on the municipal budget

- Reallocate responsibilities, giving the municipality responsibility for actions related to basic care (a greater number), and giving the state responsibility for those of medium and high complexity (these are fewer in number and higher in value) (according to the three funding components of the Pharmaceutical Policy)

- Work together with the Municipal Attorney

- Demonstrate what the municipality's economic gains would be if the Union passed on the value of the shared responsibilities

This was a laborious step, as it required a great deal of reflection on all the actions, expert knowledge of the flow of lawsuits within the city, and especially so as it became evident what really should be done to achieve the objective, and ensure that the proposed actions were feasible.

\section{Tactical-operational moment}

The Tactical-Operational Moment represents the decisive moment when the previous analysis is transformed into concrete actions. It has three components: the financial resources needed to implement the plan have been confirmed; the main actors and the partners for its implementation have been identified; and the deadlines and monitoring indicators needed to assess whether the steps have been accomplished have been confirmed (Lacerda et al., 2016).

The outcomes that resulted from implementing the operational plan are summarized in Table V.

\section{DISCUSSION}

Studies have shown that the large amount of money spent on lawsuits is a problem faced by several municipalities and states, including the Union. In the State of Sao Paulo, in 2015, expenses associated with lawsuits was 1,2 million, that involve 18,045 new lawsuits. In 2016, more 50.700 lawsuits were attended (Abrange, 2016; Fapesp, 2017).

Data from the Brazilian Ministry of Health show 
TABLE IV - Tactical-operational moment matrix

\begin{tabular}{|c|c|c|c|c|c|}
\hline \multirow[b]{2}{*}{ Actions } & \multirow[b]{2}{*}{$\begin{array}{l}\text { Financial Resources } \\
\text { (Required / } \\
\text { Estimated) }\end{array}$} & \multicolumn{2}{|c|}{ Responsibility and Centrality } & \multirow[b]{2}{*}{$\begin{array}{l}\text { Deadline for } \\
\text { Actions }\end{array}$} & \multirow[b]{2}{*}{$\begin{array}{l}\text { Indicator of } \\
\text { Evaluation } \\
\text { (Operation) }\end{array}$} \\
\hline & & $\begin{array}{c}\text { Principal } \\
\text { Actor (Organ } \\
\text { or Sector or } \\
\text { Technical) }\end{array}$ & $\begin{array}{c}\text { Other Partners } \\
\text { (Organ or Sector / } \\
\text { Technical) }\end{array}$ & & \\
\hline \multirow{2}{*}{$\begin{array}{l}\text { Bring together } \\
\text { all technical staff } \\
\text { responsible for the } \\
\text { technical advice } \\
\text { for defense of the } \\
\text { municipality, combine } \\
\text { the procedures that will } \\
\text { be done, and establish a } \\
\text { standard form for these } \\
\text { cases. }\end{array}$} & \multirow[b]{2}{*}{ None } & $\begin{array}{c}\text { Judicial } \\
\text { Actions } \\
\text { Department }\end{array}$ & & & \multirow[b]{2}{*}{$\begin{array}{c}\text { Meeting } \\
\text { attendance list; } \\
\text { Standard form } \\
\text { for technical } \\
\text { defense }\end{array}$} \\
\hline & & $\begin{array}{c}\text { Health } \\
\text { Department }\end{array}$ & Health Secretary & $\begin{array}{l}\text { December } \\
2014\end{array}$ & \\
\hline $\begin{array}{l}\text { Direct negotiations } \\
\text { with the Secretary of } \\
\text { the State of Sao Paulo } \\
\text { on the attendance of } \\
\text { shared actions, so that the } \\
\text { municipality meets all } \\
\text { the injunctions referring } \\
\text { to the primary care items } \\
\text { and the state addresses } \\
\text { the items of greater } \\
\text { complexity. }\end{array}$ & $\begin{array}{l}\text { For the municipality, } \\
\text { there will be a } \\
\text { reduction of the } \\
\text { expenses with lawsuits, } \\
\text { but it will increase } \\
\text { the number of actions } \\
\text { taken and will result } \\
\text { in a greater need for } \\
\text { human resources. }\end{array}$ & $\begin{array}{l}\text { Judicial } \\
\text { Actions } \\
\text { Department }\end{array}$ & $\begin{array}{l}\text { Request of the } \\
\text { Secretary of the State } \\
\text { of Sao Paulo }\end{array}$ & $\begin{array}{l}\text { Negotiations } \\
\text { with each new } \\
\text { court order }\end{array}$ & $\begin{array}{l}\text { Numerical } \\
\text { data }\end{array}$ \\
\hline \multirow{2}{*}{$\begin{array}{l}\text { Write a term of } \\
\text { agreement to } \\
\text { comply with court } \\
\text { orders, defining the } \\
\text { responsibilities of each } \\
\text { institution. }\end{array}$} & \multirow{2}{*}{ None } & $\begin{array}{c}\text { Judicial } \\
\text { Actions } \\
\text { Department } \\
\end{array}$ & \multirow{2}{*}{$\begin{array}{c}\text { Health Secretary; } \\
\text { Legal Matters } \\
\text { Secretary }\end{array}$} & \multirow{2}{*}{$\begin{array}{l}\text { December } \\
2014\end{array}$} & \multirow{2}{*}{$\begin{array}{c}\text { Term of written } \\
\text { agreement }\end{array}$} \\
\hline & & $\begin{array}{l}\text { Municipal } \\
\text { Attorney }\end{array}$ & & & \\
\hline $\begin{array}{l}\text { Carry out a survey of } \\
\text { the actions shared by } \\
\text { the municipality and the } \\
\text { Union. }\end{array}$ & None & $\begin{array}{c}\text { Judicial } \\
\text { Actions } \\
\text { Department }\end{array}$ & Municipal Attorney & $\begin{array}{l}\text { December } \\
2014\end{array}$ & Report \\
\hline $\begin{array}{l}\text { Provide all proofs of } \\
\text { delivery of the items } \\
\text { relating to the shared } \\
\text { actions. }\end{array}$ & None & $\begin{array}{c}\text { Judicial } \\
\text { Actions } \\
\text { Department }\end{array}$ & Municipal Attorney & $\begin{array}{l}\text { December } \\
2014\end{array}$ & Receipts. \\
\hline $\begin{array}{l}\text { Prepare a report defining } \\
\text { the Union's financial } \\
\text { responsibility for } \\
\text { reimbursement of the } \\
\text { municipality. }\end{array}$ & None & $\begin{array}{l}\text { Judicial } \\
\text { Actions } \\
\text { Department }\end{array}$ & $\begin{array}{l}\text { Municipal Attorney; } \\
\text { Health Secretary; Legal } \\
\text { Matters Secretary }\end{array}$ & $\begin{array}{l}\text { December } \\
2014\end{array}$ & Report \\
\hline
\end{tabular}

that health-related lawsuits have been increasing year by year. Study conducted in different states of Brazil have attempted to explain the judicialization phenomenon, identify the general profile of lawsuits, draw inferences on the claims, describe the various issues involved, and propose alternatives ways of solving the problems (Gomes, Amador, 2015). The analyses performed, however, focused mostly on technical and legal issues, while giving 
TABLE V - Outcomes of the operations and actions implemented through the elaboration of the operational plan

\begin{tabular}{|c|c|c|c|}
\hline Operations & Actions & Status & Pendencies \\
\hline $\begin{array}{l}\text { Establish criteria for technical } \\
\text { defense of the municipality } \\
\text { with the Municipal Health } \\
\text { Department to provide } \\
\text { support to the judiciary for the } \\
\text { exclusion of the municipality } \\
\text { from these actions. }\end{array}$ & $\begin{array}{l}\text { Bring together all technical } \\
\text { staff responsible for technical } \\
\text { advice to the municipality's } \\
\text { defense, combine the } \\
\text { procedures that will be } \\
\text { undertaken, and establish a } \\
\text { standard form for these cases. }\end{array}$ & Finalized & No pendencies \\
\hline \multirow[t]{2}{*}{$\begin{array}{l}\text { Transfer the attendance of } \\
\text { these lawsuits to the state. }\end{array}$} & $\begin{array}{l}\text { Direct negotiations with the } \\
\text { Secretary of the State of Sao } \\
\text { Paulo on the attendance of } \\
\text { shared actions, so that the } \\
\text { municipality meets all the } \\
\text { injunctions referring to the } \\
\text { primary care items and the } \\
\text { state receives the items of } \\
\text { greater complexity. }\end{array}$ & $\begin{array}{l}\text { Held at each new joint } \\
\text { lawsuit received by the City }\end{array}$ & $\begin{array}{l}\text { Lack of support from } \\
\text { the agreement between } \\
\text { the Federated Entities } \\
\text { (municipality and state) }\end{array}$ \\
\hline & $\begin{array}{l}\text { Write terms of agreement to } \\
\text { comply with court orders, } \\
\text { defining the responsibility of } \\
\text { each institution. }\end{array}$ & Finalized & $\begin{array}{l}\text { Waiting for the approval of } \\
\text { the Municipal Secretary and } \\
\text { presentation of the agreement } \\
\text { term on the CIB for approval } \\
\text { and signature. }\end{array}$ \\
\hline \multirow[t]{3}{*}{$\begin{array}{l}\text { Document the Union's shared } \\
\text { actions attended to by the } \\
\text { municipality. }\end{array}$} & $\begin{array}{c}\text { Carry out a survey of } \\
\text { shared actions between the } \\
\text { municipality and the Union. }\end{array}$ & Finalized & $\begin{array}{l}\text { Checking must be carried out } \\
\text { periodically, so that it can be } \\
\text { charged. }\end{array}$ \\
\hline & $\begin{array}{c}\text { Provide all proofs of delivery } \\
\text { for the items relating to the } \\
\text { shared actions. }\end{array}$ & Finalized & $\begin{array}{l}\text { Each new charge must be } \\
\text { provided with new proofs of } \\
\text { delivery signed by the patients, } \\
\text { or responsibility for informing } \\
\text { them that they have received } \\
\text { the product. }\end{array}$ \\
\hline & $\begin{array}{l}\text { Prepare a report defining the } \\
\text { Union's financial portion } \\
\text { of the responsibility in } \\
\text { the reimbursement of the } \\
\text { municipality. }\end{array}$ & Finalized & $\begin{array}{l}\text { Awaiting the approval of the } \\
\text { municipal secretaries and } \\
\text { the mayor to effectuate the } \\
\text { collection. }\end{array}$ \\
\hline
\end{tabular}

little attention to the political and social aspects that constrain municipalities' governance of the phenomenon. Previous findings reported in the literature and the practice of municipal management also demonstrate the need for further discussion on the topic of the judicialization of medicinal products. Based on Article 196 of the Federal Constitution, "Health is a right of all and a duty of the State" (Brazil, 1988). Gonçalves (2012) affirms that it is the responsibility of the public power, through economic and social policies, to establish conditions that ensure the fulfillment of this right, by ensuring access to health for all.

In the case study reported in this research, planning helped to advance activities that depended on the Judicial
Actions Department. It is important to highlight that the phenomenon of judicialization is somewhat strange for the health services governance - it became as an intervention in health services management, something diverse from the usual knowhow of health workers. Specialized departments have been created in many municipalities to deal with this issue, increasing costs to support the services and incorporating the judicialization as a "public health service" in controversy to the Public Health Policy.

The general objective of the OP was achieved, and the municipality's costs for legal actions decreased, because some high cost medicines dispensing and payment for procedures were transferred to the state of São Paulo. 
At this time, each new judicial action the municipality receives - for which the responsibility is shared by the Federated issues, and the state assumes responsibility for those that are of medium and high complexity of care. These extrajudicial negotiations have produced positive results for the Department, and resulted in considerable savings. Nevertheless, the negotiations between public managers, judiciary and patients must go forward to achieve a better agreement about right to health, individual and collective rights and SUS management. The negotiations have started from sharing costs responsabilities within government levels, but it do not solve the question at all.

The great advance enabled by strategic planning was to initiate dialogue between all the subjects involved in an act of planning, considering political feasibility as the central issue. Formulating a strategic approach breaks with normativity, and acknowledges conflicts between social forces, which in turn facilitates further analysis and building political viability into the planning process (Barreto et al., 2016).

Another important gain achieved by the OP was standardization of the municipality's technical defense for lawsuits related to health, and today there is a standardized form to help the professionals involved in this task.

Santana and contributors (2014), through a case study of the OP and the application of PES principles, demonstrated that they served to overcome difficulties during the implementation of Pharmacy and Therapeutics Commissions in the hospital services of the State of Sergipe. The experience described above illustrates that in addition to political will, Matus' precepts of participation, transparency, and negotiations between different sectors and interests, when applied in PES, help to rupture the operational barriers that often characterize public services.

It can be verified that the OP had some impact on the municipality's health budget, since the team incorporated the OP as a tool, and the PES dictated the process to be followed. It is important to highlight that there are different ways of involving professionals in the planning process, since adherence to the plan cannot be based solely on the participation of professionals during moments of focused discussions, but must also be expressed in their daily operational activities and actions, and be evident in the results (Artmann, Azevedo, Sá, 1997). Governability of the system, according to Matus, depends on building strong alliances between the people who support a project, and so creating conditions more favorable to actualizing the project. This means that it is important to reduce resistance to a developed project, which, in this way, becomes viable and feasible (Barreto et al., 2016). In the tactical-operational moment it was possible to develop indicators that could be used to monitor and evaluate the plan's implementation process. According to Tanaka and Melo (2004), all those involved in the planning and execution of these actions should conduct the evaluation.

The process described here points out that management should be guided by a participatory, decentralized planning process that favors the construction of an objective image. The different actors involved must agree that management is a technical, political, and social process, capable of producing the desired results (Guimarães et al., 2004).

\section{CONCLUSION}

The judicialization of health is a complex issue, and due to its remarkable growth, has aroused the interest of many sectors in various SUS management levels. For this reason, it was both challenging and necessary to implement an operational plan for this issue premised on Strategic Situational Planning for the professionals employed in the Judicial Actions Department of a municipality in the State of São Paulo.

Although the servers involved in the flow of lawsuits use the word planning on a daily basis, the methodology used for this study was unknown to the actors who participated in the workshop. Thus, in addition to advancing the OP, this work also facilitated the dissemination of the proposed OP, and strengthened the likelihood that strategic planning would be incorporated into the daily delivery of health services. Although the top priority problem was not fully addressed, the results were positive, and all actors were satisfied, so that a commitment to ensuring that all actions are carried out continues. The result described here is just a small one, but is the start for a more collaborative, participatory and organized way to understand the problems faced by public management.

The PES encourages those involved to analyze reality by considering different points of view. This project mobilized several actors, who believed in the operational plan, to contribute to its elaboration and implementation. It also helped to strengthen the multidisciplinary team and confirm the pharmacist's key role in leading pharmaceutical services and supply management.

\section{REFERENCES}

Abrange. Associação Brasileira de Planos de Saúde. Apresentação: Perfil das Ações judiciais em saúde no Estado de São Paulo. Disponível em: https://www.abramge.com.br/ congresso/2016/apresentacao/apresentacao-congresso-2016daivd-uip.pdf. 2016. 
Artmann E, Azevedo C, Sá MC. Possibilidades de aplicação do enfoque estratégico de planejamento no nível local de saúde: análise comparada de duas experiências. Cad Saúde Pública. 1997;13(4):723-740.

Barreto JL, Guimarães MCL. Avaliação da gestão da assistência farmacêutica básica em municípios baianos, Brasil. Cad Saúde Pública. 2010;26(6):1207-1220.

Barreto JL, Campese M, Santos SMC, Guimarães MCL. Operacionalização de um processo de planejamento. In: Leite SN, Soares L, Mendes SJ, Vilvert AF, Schneider LMC. (org.). Gestão da Assistência Farmacêutica. Florianópolis: EDUFSC, 2016. 160 p. (Assistência Farmacêutica no Brasil: Política, Gestão e Clínica; v. 2).

Bireme/Opas/Oms. Relato de Experiência. [Acesso em: 18 fev. 2015]. Disponível em: http://www.paho.org/bireme/index. php?option $=$ com_content $\&$ view $=$ article $\&$ id $=156$ : biremedefine-metodologia-para-qrelato-de-experienciasq \&Itemid $=7$ $3 \&$ lang $=\mathrm{pt}$.

Brasil. Constituição (1988). Constituição da República Federativa do Brasil: promulgada em 5 de outubro de 1988. Diário Oficial da União, Brasília: Senado, 1988.

Brasil. Conselho Nacional de Saúde. Resolução no 338 de 6 de maio de 2004. Aprova a Política Nacional de Assistência Farmacêutica. Diário Oficial da União, Poder Executivo, Brasília, DF, 20 de maio de 2004.

Brasil. Ministério da Saúde. Secretaria de Ciências, Tecnologia e Insumos Estratégicos. Departamento de Assistência Farmacêutica. Planejar é preciso: uma proposta de método para aplicação à assistência farmacêutica. Brasília, DF: Ministério da Saúde, 2006.

Brasil. Ministério da Saúde. Portaria $n^{\circ} 1.554$, de 30 de julho de 2013. Dispõe sobre as regras de financiamento e execução do Componente Especializado da Assistência Farmacêutica no âmbito do Sistema Único de Saúde (SUS). Diário Oficial da União. 31 jul 2013.

Brasil. Portal saúde - SUS. Departamento da Assistência Farmacêutica. [Acesso em 04fev2016]. Disponível em: http:// portalsaude.saude.gov.br/index.php/o-ministerio/principal/ secretarias/sctie/daf.

Chieffi AL, Barradas RCB, Golbaum, M. Legal access to medications: a threat to Brazil's public health system? BMC Health Serv Res. 2017;17(1):499.
Fapesp. Fundação de Amparo à Pesquisa do Estado de São Paulo. Demandas crescentes. Revista Pesquisa. Ed. 252. Set. 2017. Disponível em: http://revistapesquisa.fapesp. br/2017/02/10/demandas-crescentes/.

Gomes VS, Amador TA. Estudos publicados em periódicos indexados sobre decisões judiciais para acesso a medicamentos no Brasil: uma revisão sistemática. Cad Saúde Pública. 2015;31(3):451-462.

Gonçalves LM. O direito fundamental social à saúde: do biopoder às audiências públicas de saúde como instrumentos da democracia deliberativa. Faculdade de Direito do Sul de Minas, 2012. [Acessado em 10/07/2015]. Disponível em: http://www. fdsm.edu.br/site/posgraduacao/dissertacoes/19.pdf.

Guimarães MCL, Santos SMC, Melo C, Filho AS. Avaliação da capacidade de gestão de organizações sociais: uma proposta metodológica em desenvolvimento. Cad Saúde Pública. 2004;20(6):1642-1650.

Junquilho GS. Gestão e ação gerencial nas organizações contemporâneas: para além do "folclore" e o "fato". Rev Gestão Prod. 2001;8(3):304-318.

Lacerda JT, Veber AP, Colusi CF, Barreto JL, Calvo MC. Planejamento em Saúde. In: Leite SN, Soares L, Mendes SJ, Vilvert AF, Schneider LMC. (Org.). Gestão da Assistência Farmacêutica. Florianópolis: EDUFSC; 2016. 160 p. (Assistência Farmacêutica no Brasil: Política, Gestão e Clínica; v.2).

Leite SN, Guimarães MCL, Rover MRM, Mendes SJ. Gestão da Assistência Farmacêutica. In: Leite SN, Soares, L, Mendes SJ, Vilvert AF, Schneider LMC (Org.). Gestão da Assistência Farmacêutica. Florianópolis: EDUFSC; 2016. 160 p. (Assistência Farmacêutica no Brasil: Política, Gestão e Clínica; v. 2).

Matus C. Política, Planejamento \& Governo. Brasília: Ed. IPEA; 1993.

Mutale W, Mwanamwenge MT, Balabanova D, Spicer N, Ayles $\mathrm{H}$. Measuring governance at health facility level: developing and validation of simple governance tool in Zambia. BMC International Health and Human Rights; 2013.

Rivera FJU. Argumentación y construcción de validez en la Planificación Estratégica-Situacional de Matus. Cad Saúde Pública. 2011;27(9):1847-1857. 
Santana RS, Lobo MF, Penaforte TR, Leite SN, Silva, WB. A institucionalização da seleção de medicamentos em hospitais públicos por meio do planejamento estratégico situacional. Rev Adm Pública. 2014;48(6):1587-1603.

Santos RI, Farias MR, Pupo GD, Trindade MCN, Dutra FF. (Org.). Políticas de saúde e acesso a medicamentos. Florianópolis: EDUFSC; 2016. 224 p. (Assistência Farmacêutica no Brasil: Política, Gestão e Clínica; v. 1).

Siddiqia, S, Masuda TI, Nishtarb S, Petersc DH, Sabria B, Khalif MB, Jamaa MA. Framework for assessing governance of the health system in developing countries: Gateway to good governance. Health Policy. 2009;90(1):13-25.
Spinelli H. El proyecto político y las capacidades de gobierno. Salud Colectiva. 2012;8(2):107-130.

Tanaka OY, Melo C. Avaliação de Programas de Saúde do Adolescente: Um Modo de Fazer. São Paulo: EDUSP; 2004.

Who. World Health Organization. Health Systems Governance for Universal Health Coverage. Action Plan. Department of Health Systems Governance and Financing. Geneva: WHO; 2014.

Received for publication on $10^{\text {th }}$ October 2017 Accepted for publication on $23^{\text {rd }}$ September 2018 